\title{
16
}

\section{THE IRAN-CONTRA AFFAIR AND THE AFGHAN TASK FORCE}

\author{
Lessons in covert action
}

\author{
Jack Devine and Amanda Mattingly
}

When President Ronald Reagan came to office in 1981, he brought with him a new national security team with a focus on defeating the Soviet Union and winning the Cold War. For Reagan and his team, this meant taking the fight to the Soviets, their surrogates, and the nation-states they threatened. The Cold War saw several proxy wars, but none were as consequential as those fought on Reagan's watch, including the conflicts in Nicaragua and Afghanistan.

Both conflicts involved the arming of rebel militias - the Contras in Nicaragua and the mujahidin in Afghanistan-against a communist threat. The similarities end there. These conflicts and the handling of them could not have been more different. The Afghan Task Force was regarded as a great success, and driving the Russians from Afghanistan was the last real battle of the Cold War. In contrast, U.S. efforts in Nicaragua were much less effective, and the mistakes made and legal lines crossed in arming the Contras against the Sandinista National Liberation Front almost led to the undoing of Reagan's own administration.

The Central America operation-turned-scandal, which will forever be known more broadly as the "Iran-Contra Affair," underscores the importance of "good" covert action and is a cautionary tale about what happens when it is not executed properly. This chapter examines these two covert action case studies. It then explores key lessons learned in why covert action largely failed in Nicaragua but succeeded in Afghanistan.

\section{Taking the fight to the Soviets}

President Reagan entered the White House with the conviction that the United States needed to take a tougher line with its enemies. This meant bringing in a national security team composed of three main heavyweights: Secretary of State George Schultz, Secretary of Defense Casper "Cap" Weinberger, and Central Intelligence Agency (CIA) Director William "Bill” Casey. While they sparred among themselves over turf issues, they all had a close relationship with Reagan and shared his foreign policy vision.

All three had served in senior positions during the Nixon and Ford administrations. In addition, Casey had served as chief of staff for Reagan's campaign, playing a major role in his victory. During World War II, he worked for the Office of Strategic Services - the CIA's predecessor organization-where he served as the head of its Secret Intelligence Branch in Europe.

Reagan's national security team moved quickly to assert American resolve and shift the balance of power, especially as it related to the Soviet Union, with the clear intention to bring the fight to the Soviets. Casey immediately began to push for robust covert action activities and tougher, more pointed National 
Intelligence Estimates on the USSR. He made important personnel changes more in line with his aggressive approach to intelligence, not all of which sat well at the CIA, Congress, and the White House. It was clear Reagan intended to take the battle to the Soviets and their allies, and Casey did not want to become bogged down in debate over the president's foreign policy objectives- he too wanted to bleed the Soviet Union dry. ${ }^{1}$

Consistent with Reagan's goals, Casey sought to press hard on the Soviets in Central America and Afghanistan. This provided a boost in morale to the CIA work force, but it also came with downside risks, which later surfaced in the case of Central American operations.

\section{Outsized focus on Central America}

President Reagan's national security team held the strong conviction that the Soviet Union had plans to penetrate the governments of Central America and to bring the region into the Soviet sphere of influence as a way of undermining the United States. ${ }^{2}$ They also believed that the Cubans planned to foment revolution throughout the region, starting with Nicaragua, where leftist Sandinista revolutionaries overthrew long-time dictator Anastasio Somoza Debayle in July 1979.

Right from the start, Reagan and his team fixated on the proximity of Central America to the United States and thus focused on defending it from the Soviet threat. Casey looked upon the Sandinista government as a serious risk to U.S. national security, and Ambassador to the United Nations Jeane Kirkpatrick concurred with the assessment, famously stating, "Central America is the most important place in the world for the United States today."3

Casey's assertions were supported by a Special National Intelligence Estimate, entitled "Soviet Policies and Activities in Latin America and the Caribbean," published by the CIA in June 1982. In this report, the intelligence community spelled out clearly their judgment that the Soviet Union had begun to target Central America, and Nicaragua in particular, as an area of increased interest and activity. ${ }^{4}$

Furthermore, the report asserted that the Soviet objective in the region was to help their Cuban allies to successfully penetrate Nicaragua and aid the Sandinistas and their leader, Daniel Ortega. The Soviet strategy, per the document, included sending hundreds of Russians to assist their Cuban counterparts; training the Nicaraguan military and intelligence service; and committing millions to finance farming, infrastructure, and communications projects in Nicaragua. ${ }^{5}$ For Reagan's national security team, evidence of Soviet interest and activity in Nicaragua was clear, and their intentions to fight against Soviet influence intensified as a result.

In 1982, Reagan also signed National Security Decision Directive 17, authorizing the CIA to recruit and support rebels known as the "Contras" against the Sandinistas. ${ }^{6}$ In December 1982, Congress approved $\$ 19$ million in aid to support the Contras in a classified appropriations bill. ${ }^{7}$ This program became an integral part of the "Reagan Doctrine" in rolling back communism and giving military support to groups opposing communist, leftist governments.

Later that year, Reagan delivered a speech in Costa Rica that was broadcast throughout the region calling on the countries of Central America to join in a "peaceful revolution for democracy." The pointed statements came as a warning to the communists in the region and amid questions about CIA agents in Honduras. Reagan would not confirm it at the time, but consistent with this policy line, Casey was quickly setting in motion a major covert action operation in Central America that became the hallmark of his tenure as director of central intelligence.

Significantly, Casey replaced a highly respected and experienced Latin American operator, Nestor Sanchez, with Duane "Dewey" Clarridge as chief of the Latin America Division. Sanchez apparently was too cautious for Casey's taste. Clarridge was a Middle East hand who matched Casey's WWII-era Office of Strategic Services style of operating and had a reputation for pushing the envelope. Although Clarridge had no area knowledge or Spanish language skills, he was a strong leader and developed a loyal following among 
many Latin America Division officers. For his part, Clarridge was only too eager to accept Casey's vision about the Soviet-Cuban threat and energetically threw himself into organizing an exile force in opposition to the Sandinistas based in Honduras. ${ }^{9}$

This Casey-Clarridge covert action operation began as an authorized effort to prevent arms from being shipped from Nicaragua into surrounding countries, specifically to the leftist rebels in El Salvador, but quickly morphed into support for the Contra rebels to oust the Sandinistas in Managua. Casey and others in the administration subscribed to the "Domino Theory" and feared that if Nicaragua fell prey to communism, then it would be the first of many other Central American countries to fall. This same theory led to the U.S. intervention in Grenada in $1983 .^{10}$

The theory was not unique to the Reagan administration. In the early 1970s, for example, President Richard Nixon, Secretary of State Henry Kissinger, and CIA Director Richard Helms feared that a socialist satellite in Chile could be contagious in the region. Indeed, fear of the "falling domino" 11 had been part of the U.S. foreign policymaking lexicon in Latin America going back to the John F. Kennedy administration — when Fidel Castro proclaimed Cuba a communist state in 1961—and arguably before that in Guatemala in the 1950s.

As a result, providing support to the Contra rebels in opposition to the Sandinistas became a top priority for the Reagan administration in the 1980s. Based on the intelligence viewed by Casey, it was clear that the Sandinistas had close ties to Fidel Castro in Cuba and that many Cuban and Soviet advisors were assisting in Nicaragua. ${ }^{12}$

Additionally, the Cuban Missile Crisis of 1962 was never far from mind. The fear that the Soviets would deliver fighter jets and other military aircraft to Nicaragua by way of the Punta Huete airfield northeast of Managua — an airfield that was constructed in the early 1980s with Soviet and Cuban funds-was very real at the time, and the intelligence community monitored the movements at the airfield closely. ${ }^{13}$

The prevailing sentiment regarding Central America was clear: "If we can't stop Soviet expansionism in a place like Nicaragua, where the hell can we?" ${ }^{14}$ This made sense to Clarridge, but others in the Latin America Division of the CIA had differing views from the beginning about how to block the Sandinistas, how best to pursue a covert action program, and whether it would be more productive to apply political and economic pressure on Nicaragua.

Nevertheless, the Latin America Division focused on building up an exile, rebel force made up of disparate groups-including ex-Somoza National Guard soldiers and disillusioned ex-Sandinista insurgentswho would be trained by Argentine military forces in Honduras. They would be known as the Contras, and Clarridge continued to maintain that they "would be in Managua by Christmas" of 1983, as Honduran General Gustavo Alvarez had said to Senator Patrick Leahy during a trip to the region. ${ }^{15}$

\section{Covert action case study: arming the Contras of Nicaragua}

As time went on, the Central America covert action program became increasingly controversial, with growing opposition to supporting the Contras. In a speech in early 1985, President Reagan pushed back against these critics, arguing that the Nicaraguan rebels were "our brothers" and "freedom fighters" and that they needed "proof that we care as much about the fight for freedom 700 miles from our shores as the Soviets care about the fight against freedom 5,000 miles from theirs." ${ }^{\prime 6}$ Again, the proximity of Nicaragua to America's doorstep loomed large for Reagan and his national security team.

Still, lack of public support and Congressional opposition eventually led to the Boland Amendments (1982-1984) that prevented CIA assistance to the Contras "for the purpose of overthrowing the government of Nicaragua" and ultimately outlawed providing any U.S. government funds to them. ${ }^{17}$ Casey's and Clarridge's briefings to the House and Senate Intelligence Committees did not help their cause. The committee members soon came to distrust Casey and Clarridge and felt that they were not telling the truth, or at least routinely holding back under questioning. ${ }^{18}$ 
The plan was for the Argentines to train the Contras in Honduras on the border with Nicaragua, which offered easy in-and-out access to the country for small to medium-sized attacks on critical infrastructure or political and economic targets. ${ }^{19}$

Support for these exiles within Nicaragua, however, was minimal-comparable to the lack of support in Cuba for the Cuban exiles involved in the doomed Bay of Pigs invasion in 1961. ${ }^{20}$ Lack of support inside Nicaragua meant that they were not able to provide the best on-the-ground intelligence necessary for a successful covert operation. Furthermore, they were accused of corruption and human rights abuses and should not have been considered viable partners for the CIA. ${ }^{21}$

Nevertheless, with the United States providing the funding for the Contras, the number of attacks on Sandinista targets grew. ${ }^{22}$ Some ended successfully, while others ended in disaster. The mining of Nicaragua's harbors in 1983 was among the types of ill-conceived attacks led by the Contras. The Wall Street Journal broke the story in April that year about the harbor mining, and it became the clearest example of what Congress felt were half-truths coming from the CIA and the State Department about the U.S. intervention in Nicaragua.

The CIA-led operation to mine the harbors was designed to support the Contras by cutting off weapons flows and fuel to the Sandinista government, but instead the operation became a fiasco as commercial shipping vessels continued to use the harbors. At one point, Republican Senator Barry Goldwater wrote a letter to Casey letting him know just how "pissed off" he was about the CIA-led actions in Nicaragua. ${ }^{23}$ Both Republican and Democratic members grew increasingly unhappy with what they viewed as the CIA officials' disdainful and dishonest behavior in supporting the Contras and covering it up. Congress was left in the dark.

At the end of 1983, Reagan had approved an internal authorization of 3,000 additional weapons to support the Nicaraguan Democratic Opposition, a Contra group. ${ }^{24}$ Increases in the number of forces, weapons, and funding, however, were not fully disclosed to lawmakers. This behavior virtually guaranteed that lawmakers would take punitive action against the Central American Task Force. Although in the early stages Congress permitted assistance to the Contras for other purposes such as arms interdiction, Congress shut off the entire funding as time went on, and CIA operational activity was forced to come to a halt. Casey should have listened to former CIA Director Helms' advice that "the only thing you can't tell Congress about are operations you shouldn't be doing in the first place." 25

Reagan's national security team was unwilling to take no for an answer. Caught up in the conviction of their cause, they sought other ways to support the Contras. The White House and Casey reached out to third countries and private donors to arrange funding and military supplies for the Contras, which was technically legal even though it ran against the spirit of the Boland Amendments. They obtained about $\$ 34$ million through this process. ${ }^{26}$

Since the operational program ceased to be managed by the CIA, Lieutenant Colonel Oliver North of the National Security Council (NSC) took charge. The NSC running operations was unheard of before then. North appropriately called the project "The Enterprise," which became the secret arm of the NSC staff, and for the first time in history had control over its own airplanes, ships, operatives, and Swiss bank accounts. The idea that the NSC on its own would run clandestine operations out of the White House in an effort to "work around" Congress was doomed to failure. ${ }^{27}$

At this point in 1985, a disreputable Iranian arms dealer named Manucher Ghorbanifar stepped into the picture, having won over key officials at the NSC, including North, with a poorly prepared plan to free U.S. hostages held by Hezbollah in Lebanon by arranging for the sale of U.S. arms (specifically missiles) to the Iranians. What was not clear to those at the CIA-with the possible exception of Casey-was that the proceeds from the steep markups on the weapons sales would go to supporting the Contras, in contravention of the Boland Amendments that prohibited such assistance. ${ }^{28}$

Despite strong objections to working with Ghorbanifar from those within the CIA, including from the head of the Directorate of Operations Clair George, and an insistence that Ghorbanifar be polygraphed 
(which he then failed), the NSC went ahead with their plan, and Reagan signed an executive directive to trade the missiles. ${ }^{29}$ That decision began the biggest scandal of the Reagan administration, which engulfed the CIA and threatened to take down the White House.

Now known as the Iran-Contra Affair, the plan was stunning on several levels, starting with the fact that trading missiles for hostages contradicted long-standing U.S. policy of not dealing with terrorists. At the same time, Ghorbanifar was a problematic partner. A few years earlier, the CIA had put out a "burn notice" on him, saying that he was a serial fabricator who could not be trusted. CIA field offices were prohibited from having any relationship with him. ${ }^{30}$

Moreover, continued funding of the Contras was against U.S. law. The majority of those involved in the execution of the authorized arms-for-hostages trade did not know that the money made on the deal was then being diverted to the Nicaraguan rebels. But North knew, and he implicated many others in the process. Who else had knowledge about the illegal transfer of funds in violation of the Boland Amendments is a matter of continuing controversy. Despite various investigations, it still remains unclear exactly what Reagan, Vice President George H.W. Bush, and Casey knew about the funds transfer. ${ }^{31}$

In January 1986, Reagan authorized the direct shipment of arms from the United States to Iran without informing Congress. The Pentagon's fee for the missiles was $\$ 3,500$ each, but Ghorbanifar charged the Iranians $\$ 10,000$ for the same items. The profits from the upcharge- $\$ 6.5$ million after the first 1,000 of the planned 4,000 anti-tank TOW missiles were delivered to Iran in February 1986-went to the same account that funded the Contras. ${ }^{32}$

By the summer of 1986, the Iranians began complaining about the huge markup for the missiles. In November, a pro-Syrian magazine in Lebanon, Ash-Shiraa, published a piece about the secret arms deal with Iran, and the American press began to investigate the story. ${ }^{33}$ U.S. Justice Department investigators found a memo describing a diversion of $\$ 12$ million from Iran arms sales to the Contras. On November 25 , Reagan said that he had not been fully informed about the sale of arms to Iran and that up to $\$ 30$ million had been used to support the Contras.

One of the many sad truths about the arms deal is that few hostages were released. In fact, in September 1986, radical Shia militants took two more American hostages in Lebanon, effectively replacing those they had freed, all while the United States was funneling arms to the Iranians. ${ }^{34}$ Nearly everyone involved within the U.S. government, and especially in the CIA, came to realize what a disaster the operation had been. The operation came with a significant cost in terms of Congressional and public trust. In the end, several top officials were indicted for their involvement in the Iran-Contra Affair, including North, George, Clarridge, and others who were implicated in the illegal activity.

The Nicaraguan side of the equation was not much better, considering that despite all of the money that the Reagan administration funneled to the Contras, the objectives were never met. The Contras were divided politically, accused of corruption, human rights violations, and drug trafficking, and made little impact in Nicaragua despite years of covert funding. Efforts to make the Contras into a viable military force were ultimately unsuccessful. The many setbacks for the Contras - and the fact that they were never able to secure ground-also meant that the rebel forces were removed from the key battles in Nicaragua, which were political and economic. ${ }^{35}$

It is possible that U.S. support to the Contras kept the Cubans and Russians more engaged in Nicaragua than in other countries in Central America, which allowed for modest U.S. success elsewhere. For example, efforts against the leftist Farabundo Martí National Liberation Front (FMLN) in El Salvador might have been more difficult if Sandinista leader Ortega had the opening to send weapons and trainers freely.

Nevertheless, in Nicaragua, the reality was that once the United States cut off military support for the Contras, the rebels agreed to negotiations with the Sandinistas. Under pressure from the international community, particularly from neighboring Central American countries, the Contras eventually demobilized in 1989. ${ }^{36}$ This came just ahead of elections in 1990 that resulted in a surprise win for opposition 
candidate Violeta Chamorro from the National Opposition Union over incumbent Sandinista National Liberation Front leader Daniel Ortega. ${ }^{37}$

How much of an influence the Contras ultimately had in creating the conditions for a resolution to the conflict and a democratic transition in Nicaragua is debatable. It is not unreasonable, however, to believe that the failed socialist economic policies of the Sandinistas, coupled with the collapse of the Soviet model on the other side of the globe, had much more to do with the defeat of the Sandinistas in the polls in 1990 than did U.S. support to the Contras.

\section{Covert action case study: arming the mujahidin in Afghanistan}

The Reagan Doctrine of rolling back communism and bringing the fight to the Soviets played out elsewhere in the world at the same time- - with very different results in Afghanistan than in Nicaragua. Russian troops invaded Afghanistan in December 1979, and by the time President Reagan took office, the international reaction to the invasion was already swift and negative.

According to then-NSC Director Zbigniew Brzezinski, the Reagan administration immediately launched a two-fold process to counter the Soviets. First, the United States coordinated a joint international response involving sanctions focused on the Soviet Union. Second, the United States provided weapons to the anti-Soviet Afghan mujahidin fighters. These weapons came from various sources but especially from the Egyptians and the Chinese. ${ }^{38}$ Ultimately, the effort to arm militants through the Pakistani intelligence service, the Inter-Services Intelligence, to fight off the Russians became the CIA's longest and most successful covert operation to date.

Unlike the Central American Task Force, the Afghan Task Force was low profile and did not hold the headlines like the activities in Central America. While George Crile's 2003 book Charlie Wilson's War played up the drama as well as Representative Charlie Wilson's role in supporting the mujahidin in Afghanistan, the truth is less sensational. In reality, it was a traditional CIA covert action program run in a professional manner consistent with past programs, albeit on a larger scale and with a clear and positive outcome in the context of the Cold War.

President Jimmy Carter first authorized the covert war in late 1979. In 1981, President Reagan reauthorized the program. Congressional appropriates grew from $\$ 30$ million in 1981 to $\$ 200$ million in 1984 with the purpose of funneling weapons to the mujahidin fighters. ${ }^{39}$

By 1984, it became clear that the effort was doing significant damage to the Soviet military in Afghanistan. A critical few in the administration recognized that the covert action in Afghanistan was paying off and started to question conventional wisdom that the Soviets could not be beat - a notion held even by the CIA's top Russian analysts. In 1985, Reagan signed National Security Decision Directive 166 authorizing the CIA to ramp up efforts. ${ }^{40}$ With bipartisan Congressional support, the budget tripled that year, and the relatively small Afghan office was turned into a large task force.

At the beginning of the Soviet invasion of Afghanistan, the Soviets believed that they could succeed with only limited support to the Afghan military. They thought it would be enough to just provide communications and transport support. It became clear fairly quickly that they would have to take to the battlefield themselves and engage the enemy directly in firefights.

The Afghan resistance began to grow in proportion to the Soviet troops on the ground. By 1985, the Soviet forces had increased to about 110,000 troops, including elite Spetsnaz Special Forces and the lethal Mil Mi-24 attack helicopters. On the other side of the battlefield, however, the mujahidin fighters were estimated to be about 120,000 strong. ${ }^{41}$

The Soviets' biggest miscalculation was their belief in nation-building. They thought they could build another communist country despite the tribal nature of Afghanistan and their inherent distaste of foreign occupation. The Soviet-supported Afghan army faced a high desertion rate throughout the war, and their soldiers were reluctant to engage the Afghan mujahidin in combat because they simply did not identify with 
the creation of a communist government. In fact, they only signed up on a temporary basis for a paycheck, which meant they would "duck" when the firing started.

As the war developed, a pattern unfolded with the Soviets occupying the cities and communication centers, while the mujahidin formed bands to conduct an insurgency throughout the countryside. By the end of the war, Kabul had lost control of most of the countryside.

Many experts and policymakers had underestimated the determination of the mujahidin as well as the impact of the CIA's massive military weapons buildup, including, above all, the game changing surface-toair Stinger missile. The Stinger missile was deployed to counter Soviet aircraft, especially the Mil Mi-24 helicopter, which arguably led the Kremlin to withdraw its forces from Afghanistan in early 1989 as it forced the Russians to greatly curtail their air battle and left the playing field open to the mujahidin.

The American buildup had been a full-court press. With a budget increasing to $\$ 350$ million in the summer of 1986, the Afghan Task Force managed to undertake a sizeable increase in its arms purchases from the Chinese and maintain purchase levels with the Egyptians. ${ }^{42}$ Early in the program, it was decided that the CIA would use only Soviet-type weapons to reduce the U.S. presence on the battlefield and provide the mujahidin with weapons that were interchangeable with arms seized from Soviet and Afghan storage. This is a common practice in organizing insurgencies.

By purchasing weapons from the Chinese and the Egyptians, the task force avoided becoming overly dependent on one country, reducing the risk of being shut down if the local political situation changed suddenly and restricted procurements. At the same time, the task force increased the purchase of fourwheel-drive Toyota trucks needed for the rough terrain in Afghanistan. When these trucks could not finish the last leg of the haul over the mountains, the task force then turned to mules herded across China and delivered to camps in Pakistan. As the pressure built on the battlefield in 1986, it became clear that the Soviets would have to pull up stakes if the mujahidin could maintain the pressure. Recently declassified Russian documents support this analysis. ${ }^{43}$

The timing of this build-up roughly coincided with the selection of Mikhail Gorbachev as secretary general of the Communist Party of the Soviet Union and the initiation of his reformist policies, which contributed significantly to the Soviets' decision to withdraw from Afghanistan. Gorbachev "inherited a deteriorating war in Afghanistan" and the major setbacks in 1986 only intensified Gorbachev's desire for withdrawal. ${ }^{44}$ Soviet military and intelligence services started planning their exit from Afghanistan. In 1988, serious negotiations concluded with the Geneva Accords and the establishment of a United Nations program to monitor the withdrawal. ${ }^{45}$ On July 20, 1987, Moscow formally announced the departure of Soviet troops, and the last troops left Afghanistan on February 15, 1989.

The success of the covert action in Afghanistan was the result of a large and strategic effort that involved many partners - not just within the U.S. government and Congress but also international partners such as Pakistani and Saudi intelligence. Some critics of the program have argued that CIA officers on the Afghan Task Force were absentee managers to Pakistani intelligence or the mujahidin, but it was the close collaboration among these partners that led to success.

It is also important to emphasize that there is no evidence any weapons or support from the CIA ever went to Usama bin Ladin, who would establish al-Qaida in 1988. Critics who believe the CIA's covert war in Afghanistan created al-Qaida are incorrect, although the group likely benefited, even if indirectly, from the U.S. support. In fact, what made it possible for the CIA and U.S. Special Operations Forces to topple the Taliban within months of the $9 / 11$ terrorist attacks were, in large part, the tribal networks that the CIA established in Afghanistan and Pakistan in the 1980s. ${ }^{46}$

When the Islamabad CIA chief of station wrote the well-known message, "We Won," ${ }^{47}$ as the final Soviet troops crossed the Friendship Bridge on their way out of Afghanistan in 1989, the "we" meant a large number of unsung heroes in the United States and abroad who were engaged for nearly a decade in executing the CIA covert war. 


\section{Lessons learned}

The situations in Nicaragua and Afghanistan in the 1980s were quite different, but contrasting the two covert action operations is worthwhile. Why did one go so terribly awry, while the other proved successful and helped end the Cold War? Arming the Contras was not exactly like arming the mujahidin, and the attention on the issue by Reagan administration officials was not the same either. Certainly, the role of Congress could not have been more different. Yet the lessons learned from the two operations clearly demonstrate the differences between "good" and "bad" covert action.

The two case studies help to underscore the need for certain conditions for covert action to succeed. Such conditions include the following: ${ }^{48}$

Viable partners: The United States needs partners who share U.S. goals and objectives within the host nation where the covert action is targeted. The United States cannot rely on exiles outside of the country, as this can lead to miscommunication and mistakes. A base of operations contiguous to the target is also critical.

Real-time, accurate information: Covert action requires real-time information collected by foreign agents directed by the CIA. Reliance solely on spy satellites, communications intercepts, and other technologies can result in missing contextual details that can make or break an operation.

Adequate resources: Small sums of money and limited capability are at best ineffective and at worst dangerous. "Dabbling" is not enough. When policymakers direct the CIA to conduct covert action, they must equip the agency to succeed with ample funding and personnel.

Bipartisan political support: Covert action should reflect, in general terms, the wishes of the American people even if they are unaware of the operation. Like war, covert action needs support in Congress, and if there are significant detractors on either side of the aisle, then it is unlikely the covert action will succeed.

A direct threat to U.S. security: To garner support domestically and internationally, the White House must demonstrate that its adversary poses a real threat to U.S. national security and needs to be eliminated.

Proportionality: The desired outcome must be relatively commensurate with the cost and the collateral damage, particularly with regard to the possibility of civilian casualties.

A reasonable prospect for success: Before the CIA launches a covert action operation, policymakers have to possess a clear objective and have confidence-based on fact, not desire- that accomplishing the operation is possible.

With respect to the covert action operation in Nicaragua, several of the aforementioned conditions were not met, although it was not for lack of attention from the White House. The most obvious "red flag" was poor support from Congress. When the Reagan administration failed to obtain support for funding and arming the Contras, they sought alternative and illegal methods to pursue their objectives, which were therefore bound to fail. Going around Congress makes for bad covert action.

Bipartisan support in Congress is key to another required condition: adequate resources. The Boland Amendments meant that the Reagan administration did not have the funds that they would otherwise have put into the effort. Unfortunately, key officials still stuck to what was a bad plan while at the same time keeping others in the dark about illegal actions taken to fund these objectives.

In the end, the Iran-Contra Affair took down several career CIA operatives who were implicated in this illegal activity. In contrast, the Afghan Task Force had significant bipartisan support on Capitol Hill. Representatives in Congress were largely supportive of the U.S. objectives in Afghanistan and willing to provide the funding to meet those objectives.

Another major "red flag" in the failed covert action in Nicaragua was reliance on exile forces in the form of ex-Somoza National Guard soldiers and disillusioned ex-Sandinista insurgents along the border 
in Honduras. Support for these exiles within Nicaragua under the Sandinistas was minimal and has been compared to the lack of support in Cuba for those Cuban exiles who backed the failed Bay of Pigs invasion decades earlier. These exiles were seen largely as corrupt human rights abusers and thus not viable partners for the United States.

Given the lack of support inside Nicaragua for the Contras, they were also unable to provide the best real-time information to the CIA directing the operation. The fiasco in Nicaragua's harbors is an example of poor intelligence provided to those planning the operation.

In contrast, there were significant numbers of Afghan fighters and civilians who were sympathetic to the Afghan mujahidin efforts to drive out the Soviets from their country. The mujahidin were not just an exile force seeking to regain power from an opposing tribal or political force, but they wanted to take back their country from foreign occupation. This was a stark contrast to the situation in Nicaragua, but it speaks to the fact that the mujahidin proved viable partners with access and real-time information as well that helped to drive the program.

Despite the focus on Nicaragua and Central America more generally, the Reagan administration struggled to compel the public or Congress to see the threat the same way. Casey and others in the administration, including Reagan himself, were fixated on the proximity of Nicaragua to the United States. They viewed Central America as a clear and present danger on the doorstep to the United States, but they had trouble communicating this threat effectively enough to build support. Not being able to articulate the direct threat to U.S. security necessary to garner support spelled doom for the covert action plan.

In contrast, the Soviet invasion of Afghanistan was seen as a clear and direct threat to U.S. interests and security. The mujahidin's fight against the Russians in Afghanistan had strong public support, and the Afghan Task Force had bipartisan Congressional support and funding to match. Ultimately, fighting the Russians directly in Afghanistan held much more sway than fighting them indirectly in Nicaragua.

One of the most important components necessary for success in covert action is the reasonable prospect for success. Setting aside the misguided arms-for-hostages trade and the illegal diversion of funds to the Contras, the covert action program in Nicaragua was still bound to fail because the White House did not have reasonable prospects for success on the ground. Their analysis and policy decisions were shaped more by desire and fear than facts on the ground. In contrast, the Afghan Task Force ramped up significantly when real-time intelligence suggested Soviet casualties and Afghan desertions, which greatly improved the prospects for success.

Overall, the cases of Nicaragua and Afghanistan demonstrate the complexity of the secret covert action programs of the Cold War. They were costly in human and financial resources and fraught with risks to U.S. allies and interests. The results of these programs differed greatly, but the comparisons between the two case studies and the important lessons learned from both should help to craft covert action programs in the future.

\section{Notes}

1 Stephen S. Rosenfeld, “The Reagan Doctrine: The Guns of July,” Foreign Affairs, 1986.

2 Evan D. McCormick, "Introduction: Latin America and the Legacy of Ronald Reagan's 1980s," in Policy Roundtable: Reagan and Latin America (Austin: Texas National Security Review, 2018).

3 Walter LaFeber, Inevitable Revolutions: The United States in Central American (New York: W.W. Norton, 1993$), 5$.

4 CIA, Soviet Policies and Activities in Latin American and the Caribbean (Langley: Central Intelligence Agency, 1982).

5 Ibid.

6 White House, National Security Decision Directive on Cuba and Central America, NSDD 17 (Washington, DC: White House, 1982).

7 "Nicaraguan Decade: War, Ruin and Turnabout," New York Times, February 20, 1990, www.nytimes. com/1990/02/27/world/turnover-in-nicaragua-nicaraguan-decade-war-ruin-and-turnabout.html.

8 Steven R. Weisman, “Reagan Denounces Threats to Peace in Latin America,” New York Times, December 5, 1982, www.nytimes.com/1982/12/05/world/reagan-denounces-threats-to-peace-in-latin-america.html. 
9 Jack Devine, Good Hunting: An American Spymaster's Story (New York: Farrar, Straus and Giroux, 2014), 71-72.

10 Sam Tanenhaus, "The Rise and Fall and Rise of the Domino Theory," New York Times, March 23, 2003, www. nytimes.com/2003/03/23/weekinreview/the-world-from-vietnam-to-iraq-the-rise-and-fall-and-rise-of-thedomino-theory.html.

11 The "falling domino" reference, and ultimately what became the "Domino Theory," originally came from an April 7, 1954, speech by Dwight D. Eisenhower explaining the importance of Vietnam to the United States.

12 William J. Casey, "Address to the Harry J. Sievers Lectures Series" (New York City: Center for the Study of the Presidency, Fordham University, February 25, 1986).

13 Robert Vickers, "Intelligence and Punta Huete Airfield: A Symbol of Past Soviet/Russian Strategic Interest in Central America," Studies in Intelligence 60, no. 2 (2016): 13.

14 Joseph E. Persico, Casey: The Lives and Secrets of William J. Casey: From the OSS to the CIA (New York: Viking, 1990), 264.

15 William M. LeoGrande, Our Own Backyard: The United States in Central America, 1977-1992 (Chapel Hill: University of North Carolina Press, 1998), 311.

16 Gerald M. Boyd, "Reagan Terms Nicaraguan Rebels 'More Equal of Founding Fathers', New York Times, March 2, 1985, www.nytimes.com/1985/03/02/world/reagan-terms-nicaraguan-rebels-moral-equal-of-founding-fathers.html.

17 Boland Amendment, www.brown.edu/Research/Understanding_the_Iran_Contra_Affair/documents/d-nic-7.pdf.

18 Fox Butterfield, "Senior Official in C.I.A. Is Linked to North's Effort on Contra Arms," New York Times, January 21, 1987, www.nytimes.com/1987/01/21/world/senior-official-in-cia-is-linked-to-north-s-effort-on-contraarms.html.

19 Stephen Engelberg, "U.S. and the Nicaraguan Rebels: Six Years of Questions and Contradictions," New York Times, May 3, 1987, www.nytimes.com/1987/05/03/world/us-and-the-nicaraguan-rebels-six-years-of-questions-andcontradictions.html.

20 Tad Szulc, "Nicaragua, An Echo of the Bay of Pigs," New York Times, March 16, 1986, www.nytimes. com/1986/03/16/opinion/nicaragua-an-echo-of-the-bay-of-pigs.html.

21 Michael Freitag, "Sandinistas and Contras Accused of Rights Abuses," New York Times, November 18, 1987, www. nytimes.com/1987/11/18/world/sandinistas-and-contras-accused-of-rights-abuses.html.

22 White House, "CIA Covert Operations in Nicaragua" (secret presidential finding, Washington, DC: White House, September 19, 1983).

23 Doyle McManus and Robert C. Toth, "Setback for Contras: CIA Mining of Harbors 'a Fiasco'," Los Angeles Times, March 5, 1985, www.latimes.com/archives/la-xpm-1985-03-05-mn-12633-story.html.

24 Robert McFarlane, "Support for the Nicaraguan Democratic Opposition" (Memorandum to the President, Washington, DC: November 7, 1983).

25 Persico, Casey, 492.

26 Richard Sobel, "Contra Aid Fundamentals: Exploring the Intricacies and the Issues," Political Science Quarterly 110, no. 2 (1995): 287-306.

27 Devine, Good Hunting, 89.

28 Ibid., 86. "The various [Congressional] committees and commissions called dozens of witnesses but they were never able to resolve a central question about Iran-Contra: What was Bill Casey's role? Casey suffered a stroke in his office on December 15, 1986, the result of a brain tumor, which left him unable to talk and caused his death a short time later."

29 Bob Woodward and Charles R. Babcock, "CIA Warned of Ghorbanifar as 'Fabricator'," Washington Post, January 31, 1987, www.washingtonpost.com/archive/politics/1987/01/31/cia-warned-of-ghorbanifar-as-fabricator/ 22de69d3-1da0-4a9e-bdb1-03eb1c447dfb/.

30 James Bamford, “Iran: The Next War," Rolling Stone, July 24, 2006.

31 Bob Woodward, Veil: The Secret Wars of the CIA 1981-1987 (New York: Simon \& Schuster, 1987). In Woodward's book, he claims that on Bill Casey's deathbed, he told Woodward that he knew that the funds from the arms sales to Iran were used to support the Contras in Nicaragua. However, as Jack Devine wrote, "There has been much conjecture over the years about whether he [Casey] helped the NSC orchestrate the [Iran-Contra] operation." See Devine, Good Hunting, 86.

32 Bamford, "Iran: The Next War."

33 Melissa B. Mahle, Denial and Deception: An Insider's View of the CIA From Iran-Contra to 9/11 (New York: Nation Books, 2004), 29.

34 Micah Zenko, "Revising President Reagan's Iran Arms-for-Hostages Initiative," Council on Foreign Relations, August 3, 2016, www.cfr.org/blog/revisiting-president-reagans-iran-arms-hostages-initiative.

35 Editorial Board, "Why the Contras Failed," New York Times, August 20, 1989, www.nytimes.com/1989/08/20/ opinion/why-the-contras-failed.html. 
36 Mark A. Uhlig, "Five Latin Presidents Defy U.S. and Urge Contras' Eviction," New York Times, August 8, 1989, www.nytimes.com/1989/08/08/world/5-latin-presidents-defy-us-and-urge-contras-eviction.html.

37 Mark A. Uhlig, "Turnover in Nicaragua; Aristocratic Democrat; Violeta Barrios de Chamorro," New York Times, February 27, 1990, www.nytimes.com/1990/02/27/world/turnover-in-nicaragua-aristocratic-democrat-violetabarrios-de-chamorro.html.

38 Robert Pear, "Arming Afghan Guerrillas: A Huge Effort Led by U.S.," New York Times, April 18, 1988, www. nytimes.com/1988/04/18/world/arming-afghan-guerrillas-a-huge-effort-led-by-us.html.

39 Devine, Good Hunting, 25.

40 White House, U.S. Policy, Programs and Strategy in Afghanistan, NSDD 166 (Washington, DC: White House, 1985).

41 Devine, Good Hunting, 27.

42 Ibid., 37.

43 Alan J. Kuperman, "The Stinger Missile and U.S. Intervention in Afghanistan,” Political Science Quarterly 114, no. 2 (1999): 219-263.

44 Steven Coll, "Gorbachev Was Right," New Yorker, September 29, 2009, www.newyorker.com/news/steve-coll/ gorbachev-was-right.

45 Phillip Taubman, "Soviet Sets May 15 as Goal to Start Afghanistan Exit," New York Times, February 9, 1988, www. nytimes.com/1988/02/09/world/soviet-sets-may-15-as-goal-to-start-afghanistan-exit.html.

46 Devine, Good Hunting, 104.

47 Steve Coll, Ghost Wars (New York: Penguin Books, 2004), 185.

48 This list of conditions first appeared in Devine, Good Hunting. 